\title{
A FLUIDIC MUSCLE ÁLTAL KIFEJTETT ERŐ KÖZELÍTÉSÉNEK VIZSGÁLATA MS EXCEL KÖRNYEZETBEN
}

\author{
Sárosi József ${ }^{1}$-Dr. PhD Fabulya Zoltán ${ }^{2}$ \\ ' adjunktus, Szegedi Tudományegyetem Mémöki Kar \\ ${ }^{2}$ föiskolai docens, Szegedi Tudományegyetem Mérnöki Kar, Szeged
}

\begin{abstract}
SUMMARY
The newest and most promising type of pneumatic actuators is the pneumatic artificial muscle (PAM). Different designs have been developed, but the McKibben muscle is the most popular and is made commercially available by different companies (e. g. Fluidic Muscle manufactured by Festo Company and Shadow Air Muscle manufactured by Shadow Robot Company). Pneumatic artificial muscles have a wide range of use in industrial and medical fields. There are a lot of advantages of these muscles like the high strength, good power-weight ratio, low price, little maintenance needed, great compliance, compactness, inherent safety and usage in rough environments. The main disadvantage is that their dynamic behaviour is highly nonlinear.

The most often mentioned characteristic of PAMs is the force as a function of pressure and contraction. In this paper the newest function approximations for the force generated by Fluidic Muscles are investigated in MS Excel.

Kulcsszavak: Fluidic Muscle, erö, közelítő függvény, korreláció, MS Excel (Solver)
\end{abstract}

\section{BEVEZETÉS}

Noha a szakirodalmak McKibben nevét emlitik meg, mint a pneumatikus mesterséges izom (PMI) bevezetöje, de Daerden (1999) és Ramasamy et al. (2005) kiemelik, hogy az alapötlete az orosz Garasiev nevéhez füzödik és egészen az 1930-as évekig nyúlik vissza, azonban a kor anyagtechnológiai szintje csak korlátozott alkalmazást tett lehetővé. Az első igazi áttörés ténylegesen Joseph L. McKibbenhez köthető az 1950-es években, aki - miután vizsgálta az analógiát a pneumatikus és a természetes izmok között - az általa tervezett és a róla elnevezett pneumatikus izmot alkalmazta gyógyászati eszközök mozgatójaként. A gyakorlati alkalmazást azonban megnehezitette a pneumatikus energia nehéz tárolása, valamint az alacsony szintủ szeleptechnológia. Ennek köszönhetően a további fejlesztéseket leállitották, melyek csak az 1980-as években indultak újra a japán Bridgestone vállalat révén, melynek mérnökei megalkották a Rubbertuator elnevezésủ pneumatikus izmot, illetve az ilyen típusú izmokat alkalmazó - Soft Arm elnevezésủ - robotkart, mely az ipari robotikában terjedt el (Daerden 1999, Tsagarakis és Caldwell 2000, Ramasamy et al. 2005). Legújabban a Shadow Robot Company SAM (Shadow Air Muscle) és a Festo Fluidic Muscle elnevezésü termékei érhetök el a kereskedelemben.

A pneumatikus mesterséges izmok felépitése és müködési elve a szakirodalmakban részletesen dokumentált (Caldwell, Razak és Goodwin 1993, Chou és Hannaford 1996, Daerden 1999, Tondu és Lopez 2000, Daerden és Lefeber 2002). A PMI-ket a szakirodalmak eltérő névvel említik. Ezeket Daerden (1999), Daerden és Lefeber (2002), valamint Ramasamy et al. (2005) révén a következöképp foglalhatjuk össze: Pneumatic Muscle Actuator, Fluid Actuator, Fluid-Driven Tension Actuator, Axially Contractible Actuator és Tension Actuator.

Ebben a munkánkban bemutatjuk és elemezzük a Fluidic Muscle által kifejtett eröt leíró, általunk kidolgozott legújabb függvényt MS Excel környezetben. Ehhez a Festo által szabadalmaztatott és gyártott DMSP-20-200N-RM-RM tipusú Fluidic Muscle-t használjuk, mely $20 \mathrm{~mm}$ névleges átméröjü és $200 \mathrm{~mm}$ névleges hosszúságú. 


\section{A PNEUMATIKUS MESTERSÉGES IZMOK STATIKUS MODELLJE}

A PMI-k legfontosabb jellemzőjeként az állandó nyomásokon mérhető erő-kontrakció karakterisztika említhető. Az erő, az elmozdulás és a nyomás mérésére, valamint az izmok nagypontosságú pozicionálására megtervezett és megépített univerzális mérőberendezés hardver és szoftver rendszerének jó leírását adja Sárosi et al. (2009) és Sárosi et al. (2010). A mérési adatok gyủjtését és tárolását, valamint a gyors és robusztus szabályozást megvalósító csúszómód szabályozót LabVIEW fejlesztői környezetben realizáltuk.

Daerden (1999) megállapítja, hogy a pneumatikus mesterséges izmok általános viselkedése kiterjesztett állapotban - tekintettel az alakra, a kontrakcióra és a kifejtett erőre - függ a belső elasztikus rész és a fonat nyugalmi állapotban jellemző geometriai paramétereitől, valamint az izom anyagától (1. ábra és 2 . ábra).

\section{1. ábra: A PMI geometriai paraméterei}

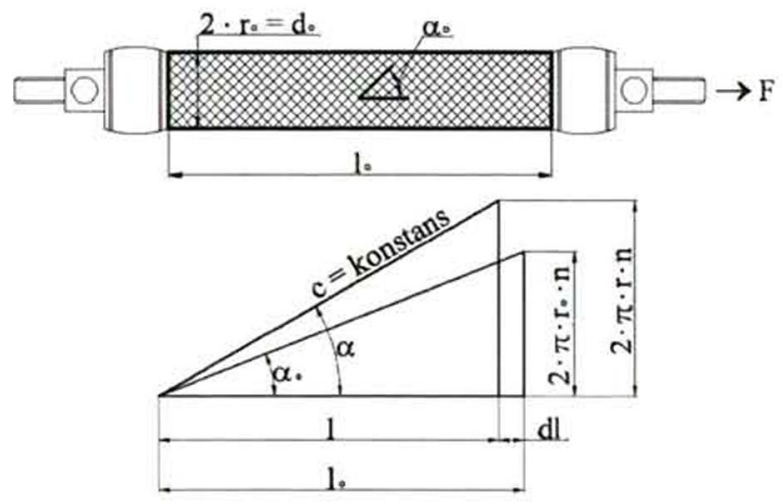

Forrás: A szerzők saját szerkesztése

2. ábra: A Fluidic Muscle szerkezeti felépítése és anyaga

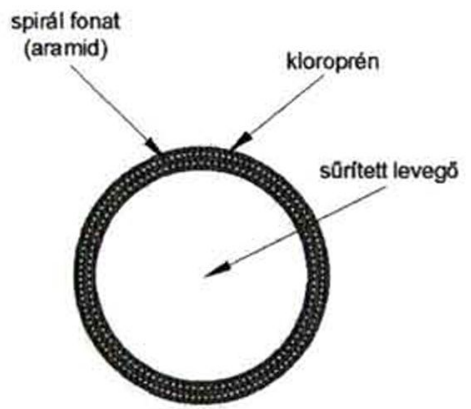

Forrás: A szerzők saját szerkesztése

Chou és Hannaford (1996), Tondu és Lopez (2000), valamint Kerscher et al. (2005) részletesen beszámol a McKibben-féle izom statikus modelljéről.

Tondu és Lopez (2000) a következöképp definiálják a PMI-k által kifejtett erőt (az 1. ábra alapján): 


$$
\begin{aligned}
& \mathrm{F}(p, \kappa)=\mathrm{p} \cdot \pi \cdot \mathrm{r}_{0}^{2} \cdot\left(\frac{3}{\operatorname{tg}^{2} \alpha_{0}} \cdot \frac{1^{2}}{1_{0}^{2}}-\frac{1}{\sin ^{2} \alpha_{0}}\right)=\mathrm{p} \cdot \pi \cdot \mathrm{r}_{0}^{2} \cdot\left(\mathrm{a} \cdot(1-\kappa)^{2}-\mathrm{b}\right) \\
& \text { Megjegyzés: } \mathrm{a}=\frac{3}{\operatorname{tg}^{2} \alpha_{0}}, \mathrm{~b}=\frac{1}{\sin ^{2} \alpha_{0}}, \kappa=\frac{\mathrm{l}_{0}-1}{\mathrm{l}_{0}} \text { és } 0 \leq \kappa \leq \kappa \max
\end{aligned}
$$

Ahol: $F$ a húzóerö, $p$ az alkalmazott nyomás, $r_{0}, l_{0}, \alpha_{0}$ a nyugalmi állapotban mérhető belső sugár, hosszúság, valamint a bezárt szög a fonat és a hossztengely között, $r, l, \alpha$ a kiterjesztett állapotban mérhető belső sugár, hosszúság, valamint a bezárt szög a fonat és a hossztengely között, $c$ a fonat hossza, $n$ a fonat menetszáma és $\kappa$ a kontrakció (relatív hosszváltozás).

Az (1) által értelmezett teoretikus eröt elöbb Tondu és Lopez (2000), majd Kerscher et al. (2005) is korrigálják. Tondu és Lopez (2000) egy $\varepsilon$ korrekciós tényezővel történő kiegészitést javasol, mert (1) az alkalmazott nyomástól függetlenül azonos maximális kontrakciót jósol. $\mathrm{Az} \varepsilon$ bevezetésével az erök egy jobb közelítését kapjuk $\mathrm{p} \geq 200 \mathrm{kPa}$ nyomás esetén. Kerscher et al. (2005) pedig a $200 \mathrm{kPa}$-nál kisebb nyomásra történỏ kiterjesztés érdekében tesznek javaslatot egy $\mu$ korrekciós tényező bevezetésére. Az $\varepsilon$ és $\mu$ korrekciós tényezökkel kiegészített teoretikus egyenlet az erőre tehát:

$$
\begin{gathered}
\mathrm{F}(p, \kappa)=\mu \cdot \mathrm{p} \cdot \pi \cdot \mathrm{r}_{0}^{2} \cdot\left(\mathrm{a} \cdot(1-\varepsilon \cdot \kappa)^{2}-\mathrm{b}\right) \\
\text { Megjegyzés: } \varepsilon=\mathrm{a}_{\varepsilon} \cdot \mathrm{e}^{-\mathrm{p}}-\mathrm{b}_{\varepsilon} \text { és } \mu=\mathrm{a}_{\kappa} \cdot \mathrm{e}^{-\kappa \cdot 40}-\mathrm{b}_{\kappa}
\end{gathered}
$$

Igazoltuk, hogy (1) és (2) nagy pontatlansággal közelíti meg a méréssel nyert adatokat (Sárosi, Gyeviki és Csikós 2010, Sárosi et al. 2012), ezért kidolgoztunk és bevezettünk egy hat paraméterrel rendelkezö összefüggést az erőre, mely általánosan alkalmazható tetszőleges átméröjü és hosszúságú izmokra, tetszőleges nyomáson:

$$
\mathrm{F}(p, \kappa)=(\mathrm{a} \cdot \mathrm{p}+\mathrm{b}) \cdot \mathrm{e}^{\mathrm{c} \cdot \kappa}+\mathrm{d} \cdot \mathrm{p} \cdot \mathrm{\kappa}+\mathrm{e} \cdot \mathrm{p}+\mathrm{f}
$$

Vizsgálataink során azt tapasztaltuk, hogy a $\mathrm{d}_{0}=20 \mathrm{~mm}$ átméröjủ izmok esetén - függetlenül azok hosszúságától - tovább egyszerüsíthető (3) anélkül, hogy az illeszthetőség pontossága romlana, így az elöbbi hat ismeretlent tartalmazó modell helyett egy öt ismeretlen együtthatóval rendelkező összefüggést kaptunk:

$$
\mathrm{F}(p, \kappa)=(\mathrm{p}+\mathrm{a}) \cdot \mathrm{e}^{\mathrm{b} \cdot \kappa}+\mathrm{c} \cdot \mathrm{p} \cdot \mathrm{\kappa}+\mathrm{d} \cdot \mathrm{p}+\mathrm{e}
$$

A (3)-ban és a (4)-ben szereplö ismeretlen konstansok (a, b, c, d, e és f, valamint a, b, c, d és e) meghatározásához az MS Excel 2010 Solver bővítményét használtuk és szintén e táblázatkezelő szoftvert alkalmaztuk az illeszkedés pontosságának igazolásához.

\section{A KÖZELÍTŐ FÜGGVÉNYEK ILLESZTÉSE}

$\mathrm{Az}$ optimalizáció általános célja egy függvény szélsőértékhelyének (minimumának, maximumának) meghatározása. Az erő mért és számított értékeinek eltérésnégyzeteiből képzett összeg - mint célfüggvény - felírható: 


$$
\mathrm{S}^{2}=\sum_{\mathrm{i}=1}^{\mathrm{n}}\left(\mathrm{x}_{\mathrm{i}_{\text {metr }}}-\mathrm{x}_{\mathrm{i}_{\text {eimiont }}}\right)^{2}
$$

Jelen optimalizáció során az (5) minimalizálása a cél, vagyis a legkisebb négyzetek módszere került alkalmazásra.

Első lépésként a Fluidic Muscle által kifejtett erőt határoztuk meg mérések útján a kontrakció függvényében különböző konstans nyomásokon. Mint látható, az erő nullává válik maximális kontrakciónál, míg az erő maximális értéke külső erő hatására bekövetkező negatív kontrakciónál mérhető (3. ábra).

3. ábra: A Fluidic Muscle által kifejtett erő a kontrakció függvényében állandó nyomásokon

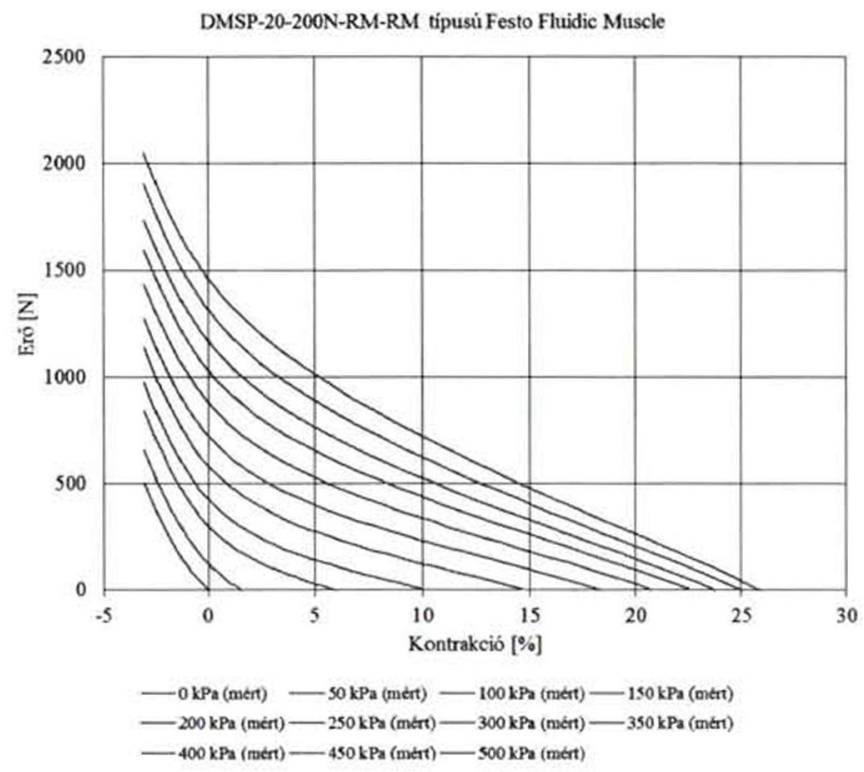

Forrás: A szerzök saját szerkesztése

A (3)-ban szereplő ismeretlen paraméterek meghatározása MS Excel környezetben, a Solver segítségével történt. Az ismeretlen paraméterek értékét az 1. táblázat tartalmazza.

1. táblázat: A (3) paramétereinek értéke MS Excel környezetben futtatott optimalizációval

\begin{tabular}{|c|c|}
\hline Paraméterek & Értékek \\
\hline a & $-5,77444505$ \\
\hline b & 292,7876858 \\
\hline c & $-0,33381012$ \\
\hline d & $-9,43297879$ \\
\hline e & 298,4843217 \\
\hline f & $-292,014125$ \\
\hline
\end{tabular}

A 4. ábrán a mért és az 1. táblázatban ismertetett paraméterértékeket felhasználó (3) összehasonlítása látható. A könnyebb áttekinthetőség érdekében csak a $0 \mathrm{kPa}, 100 \mathrm{kPa}$, $200 \mathrm{kPa}, 300 \mathrm{kPa}, 400 \mathrm{kPa}$ és $500 \mathrm{kPa}$ nyomáson kapott jelleggörbéket mutatjuk az összehasonlítás során. 
4. ábra: A mért és az (5)-tel számított értékek összehasonlítása állandó nyomásokon

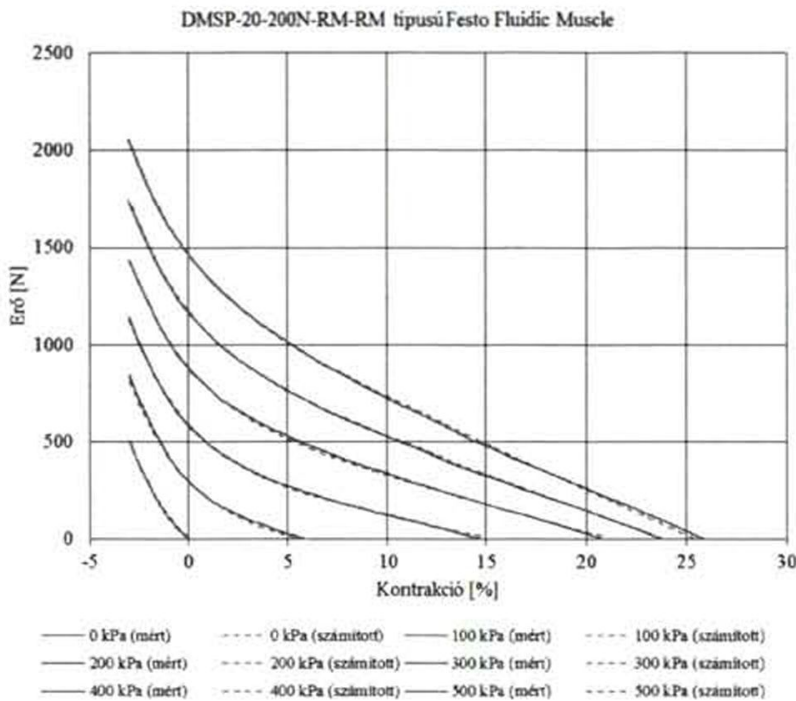

Forrás: A szerzők saját szerkesztése

$A z$ 5. ábra igazolja a kedvezö illeszthetőséget $\left(R^{2}=0,9995 \rightarrow R=0,9997\right.$ (korrelációs együttható), valamint 0,9998 meredekség értékek).

5. ábra: Korreláció és regresszió analizis MS Excel 2010 környezetben a mért és a (3)-mal számított eredmények között

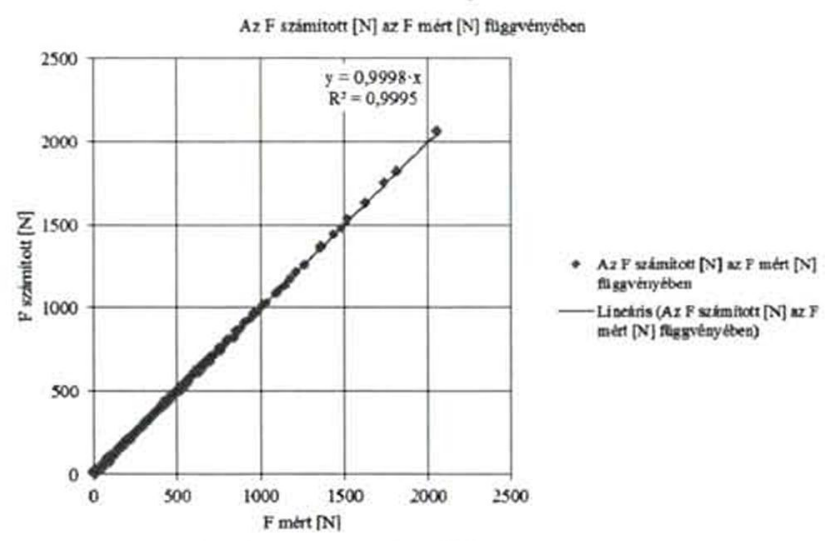

Forrás: A szerzök saját szerkesztése

Vizsgálatainkat megismételtük (4) alkalmazásával. A (4)-ben szereplö ismeretlen paraméterek értékét a 2. táblázat tartalmazza. 
2. táblázat: A (4) paramétereinek értéke MS Excel környezetben futtatott optimalizációval

\begin{tabular}{|c|r|}
\hline Paraméterek & \multicolumn{1}{|c|}{ Értékek } \\
\hline a & 285,254867 \\
\hline b & $-0,33009314$ \\
\hline c & $-9,16016808$ \\
\hline d & 291,1780491 \\
\hline e & $-281,240775$ \\
\hline
\end{tabular}

A 6. ábrán a mért és a 2. táblázatban ismertetett paramétereket felhasználó (4) összehasonlitása látható.

6. ábra: A mért és az (5)-tel számított értékek összehasonlítása állandó nyomásokon

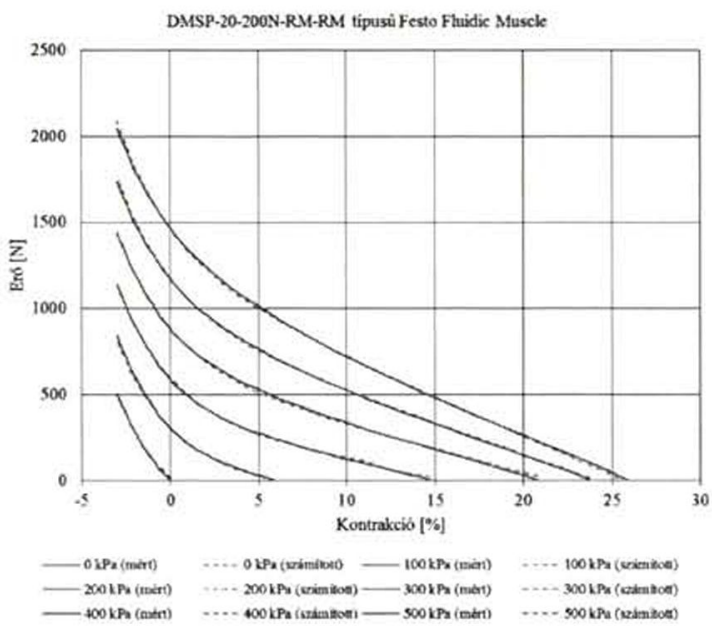

Forrás: A szerzők saját szerkesztése

Az itt tapasztalt kedvezö illeszthetőséget $\left(\mathrm{R}^{2}=0,9994 \rightarrow \mathrm{R}=0,9997\right.$ (korrelációs együttható), valamint 0,9998 meredekség értékek) a 7. ábra szemlélteti.

7. ábra: Korreláció és regresszió analízis MS Excel 2010 környezetben a mért és a (4)-gyel számított eredmények között

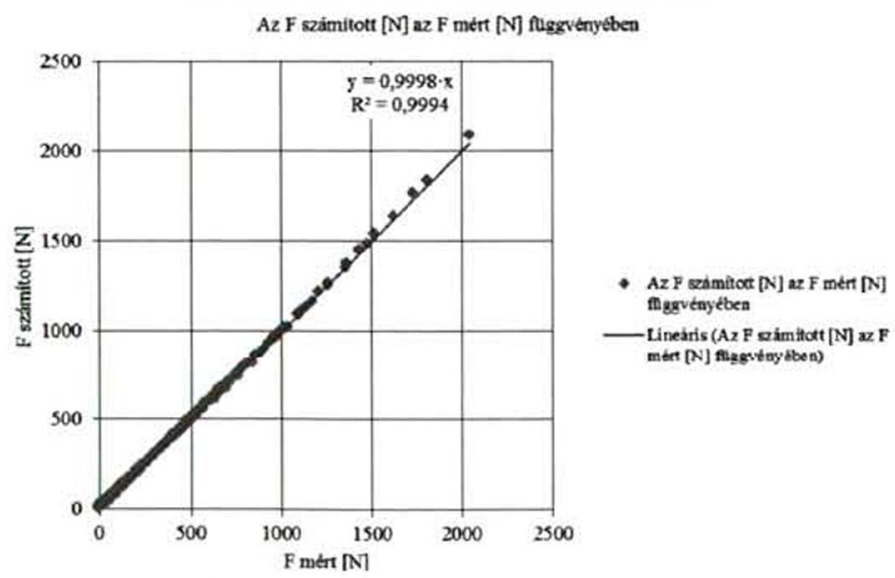

Forrás: A szerzök saját szerkesztése 


\section{KÖVETKEZTETÉSEK, JÖVŐBENI KUTATÁSI IRÁNYOK}

A szakirodalmakban leggyakrabban hivatkozott matematikai modellek a PMI-k által kifejtett erő közelitésére még különbözö korrekciós tényezök bevezetésével sem, vagy csak részben tudják megközeliteni a mérési sorozatokkal nyert értékeket, ezért egy ủj, hat, illetve öt ismeretlent tartalmazó függvénykapcsolatot dolgoztunk ki. Az ismeretlen paramétereket az MS Excel 2010 Solver bövítmény segitségével határoztuk meg. Mindkét esetben matematikai statisztikai úton igazoltuk az illeszkedés pontosságát. További célunk, hogy az erö közelítését leíró egyenletek alapján egy új matematikai formulát állitsunk fel a Fluidic Muscle-ok által kifejtett eröre.

\section{IRODALOMJEGYZÉK}

Caldwell D. G. - Razak A. - Goodwin M. J. (1993): Braided Pneumatic Muscle Actuators. IFAC Conference on Intelligent Autonomous Vehicles, Southampton, United Kingdom, 18-21 April, 1993, 507-512. p.

Chou C. P. - Hannaford B. (1996): Measurement and Modelling of McKibben Pneumatic Artificial Muscles. IEEE Transactions on Robotics and Automation, Vol. 12, No. 1, 90-102. p.

Daerden F. (1999): Conception and Realization of Pleated Artificial Muscles and Their Use as Compliant Actuation Elements. PhD Dissertation. Vrije Universiteit Brussel, Faculteit Toegepaste Wetenschappen Vakgroep Werktuigkunde, 5-33. p.

Daerden F. - Lefeber D. (2002): Pneumatic Artificial Muscles: Actuator for Robotics and Automation. European Journal of Mechanical and Environmental Engineering. Vol. 47, 10-21.p.

Festo (2005): Fluidic Muscle DMSP, with Press-fitted Connections, Fluidic Muscle MAS, with Screwed Connections. Termékkatalógus. 1-39. p.

Kerscher T. - Albiez J. - Zöllner J. M. - Dillmann R. (2005): FLUMUT - Dynamic Modelling of Fluidic Muscles using Quick-Release. 3rd International Symposium on Adaptive Motion in Animals and Machines, Ilmenau, Germany, 25-30 September, 2005, 1-6. p.

Ramasary R. - Juhari M. R. - Mamat M. R. - Yaacob S. - Mohd Nasir N. F. - Sugisaka M. (2005): An Application of Finite Modelling to Pneumatic Artificial Muscle. American Journal of Applied Sciences, Vol. 2, No. 11, 1504-1508. p.

Sárosi J. - Gyeviki J. - Véha A. - Toman P. (2009): Accurate Position Control of PAM Actuator in LabVIEW Environment. IEEE $7^{\text {th }}$ International Symposium on Intelligent Systems and Informatics. Subotica, Serbia, 25-26 September, 2009, 301-305. p.

Sárosi J. - Gyeviki J. - Szabó G. - Szendrő P. (2010): Laboratory Investigations of Fluid Muscles. International Journal of Engineering, Annals of Faculty of Engineering Hunedoara. Vol. 8, No. 1,137142. p.

Sárosi J. - Gyeviki J. - Csikós S. (2010): Mesterséges pneumatikus izomelemek modellezése és paramétereinek szimulációja MATLAB környezetben. Jelenkori Társadalmi és Gazdasági Folyamatok. Szegedi Tudományegyetem Mérnöki Kar. Vol. 5, No. 1-2, 273-277. p.

Sárosi J. - Fabulya Z. - Szabó G. - Szendrö P. (2012): Investigations of Precise Function Approximation for the Force of Fluidic Muscle in MS Excel. Review of Faculty of Engineering (International Conference on Science and Technique in the Agri-Food Business, ICoSTAF 2012), Vol. 2012/3-4, 1-8. p.

Tsagarakis N. - Caldwell D. G. (2000): Improved Modelling and Assessment of Pneumatic Muscle Actuators. IEEE International Conference on Robotics and Automation, San Francisco, CA, USA, 2428 April, 2000, 3641-3646. p.

Tondu B. - Lopez P. (2000): Modelling and Control of McKibben Artificial Muscle Robot Actuator. IEEE Control System Magazine. Vol. 20,15-38. p. 